\title{
C4B wt Allele
}

National Cancer Institute

\section{Source}

National Cancer Institute. C4B wt Allele. NCI Thesaurus. Code C128861.

Human C4B wild-type allele is located in the vicinity of $6 \mathrm{p} 21.3$ and is approximately $21 \mathrm{~kb}$ in length. This allele, which encodes complement C4-B protein, plays a role in both host defense and inflammation. The expression of this gene is associated with the expression of Chido blood group antigens. Mutation of the gene is associated with complement component C4B deficiency. Copy number variation and polymorphisms are associated with increased risk for systemic lupus erythematosus. 